\title{
Hawaii's Lei Flower Industry
}

\begin{abstract}
"A lei is not just for special occasions," my friend told me. "You can wear one anytime. When you give a lei that you have made yourself you are giving your aloha, and a part of your heart."
\end{abstract}

It is in the Hawaiian tradition to wear or to give a lei for almost any occasion. The plumeria lei is one of the most popular forms nowadays, but it has not always been so. In her book "Ka Lei, the Leis of Hawaii," Marie MacDonald recounts that plumeria was often associated with graveyards, where these trees grew in memory of the dead; for this reason, oldtimers refused to wear it. The plumeria only began to be used in leis in the 1940s. when tourist arrivals increased and there was a need for a colorful, fragrant, easy-to-string lei flower.

A yellow-flowered Plumeria rubra $L$. was introduced into Hawaii in 1860 by William Hillebrand, as one of the plants he gathered in the Orient as Commissioner of Immigration for the Kingdom of Hawaii. Plumeria is, however, native to Central America. It was spread to Asia by the Spanish, who traded between Acapulco and Manila.

Hundreds of open-pollinated seedlings have yielded a rich array of pinks, reds, yellows, whites, and multi-colored striped flowers whose fragrances range from mild and sweet through lemony, rose-like, and spicy, to heavy and woody (Chinn and Criley, 1982). An extensive collection of named cultivars is maintained by the College of Tropical Agriculture and Human Resources of the Univ. of Hawaii at Manoa, where research is presently underway to manipulate the flowering season and manage branching for ease of flower harvest.

For all its use as a lei flower flower million were reported sold in 1991), the wholesale value of plumeria remains under $\$ 500,000$ (Hawaii Dept. of Agriculture, 1991), as nearly every family has a tree or two in the yard to take care of their needs. Only 20 growers report on their sales, yet plumeria leis are seen everywhere-an incalculably effective symbol of Hawaii's tourist industry.

Commanding nearly $25 \%$ of the $\$ 4.4$ million wholesale value of lei flowers in 1990, the carnation has remained a major influence since its introduction by the missionaries, sometime before the reign of King David Kalakaua. The red and white-striped carnation bore the colors of the Hawaiian flag and, more important, it was also finely scented. Production in Hawaii for carnation lei heads has vaulted the state

Front Cover: 'Lurline' plumeria, a 1973 release by the Univ. of Hawaii, was named in honor of Lurline Matson Roth. It was selected from a population of open pollinated seedlings of ' $G$ old' parentage, which also yielded 'Kimo' (a 1970 Univ. of Hawaii release). (Photo by Richard A. Criley.) into third among those states still producing the flower. Nonetheless, flower heads are still imported to meet seasonal demands, such as spring graduation exercises.

The flowers are strung in a dense tress by removing the calyx and piercing the ovaries longitudinally to thread them on a string, while a looser "single" form is strung with the calyces intact. Depending on the style and flower size, 50 to 100 flowers may be used. Leis of miniature carnations have become increasingly popular because they weigh less and more colors are available.

Once accounting for more than half the wholesale value of lei flowers, Vanda 'Miss Joaquim' ('Miss Agnes Joaquim') slipped to $17 \%$ of the trade in 1990. Introduced from Singapore in 1925 by H.L. Lyon, a lei of this orchid flower won a $\$ 25$ prize in a May Day lei contest in 1941 (Beaumont, 1951). but became widely popular after winning grand prizes in the 1947 and 1950 contests (McDonald, 1989). A flat style of stringing the vanda became popular in which the lateral petals were removed to leave only the large lip and cup. These were strong cup to cup, with the large lip petals alternating left and right. While the vanda is long-lasting and available year-round, it does not have the fragrance of some other lei flowers. Large numbers of vandas are required for the flat or maunaloa-style lei, although only about 50 are needed for stringing "single"style through their centers.

Twenty years ago, the tuberose (Polianthes tuberosa L.) accounted for only $4 \%$ of the lei flower trade. In 1990, it was valued at $\$ 981,000$, or about $22 \%$ of the lei trade. Even this has slipped a bit; 1987 figures were $\$ 2.4$ million and $45 \%$. Susceptibility to nematodes, increased competition from other flowers, and more growers entering the market have accounted for some of the decline.

Tuberose is powerfully fragrant and only a few are needed to perfume a room, so the wearer of a tuberose lei is sure to be noticed. Most of these leis are strung longitudinally, but a unique lei can be made by piercing the flower through the sides. Tuberose is often alternated with more colorful, unscented flowers, including chrysanthemum, globe amaranth (Gomphrena globosa L.), or vanda or dendrobium orchids, as well as with minature carnations to lend a more spicy fragrance.

A steadily increasing share of the lei market is going to the dendrobium orchid. It was not until 1979 that the market reporting service of the Hawaii Dept. of Agriculture gave recognition to the dendrobium in the lei trade by giving it a line in its annual reports. At that

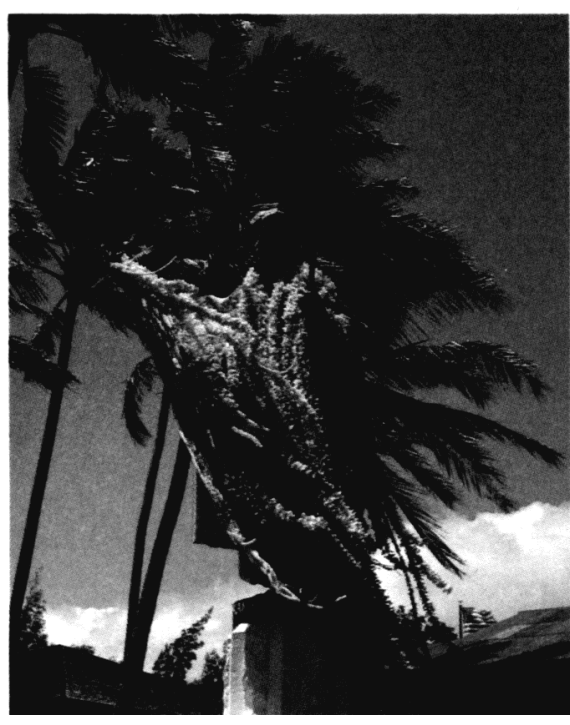

Leis decorate the King Kamehameha I statue in Hawi (Kohala district of the Island of Hawaii) in honor of the 11 June birthdate of the leader who unified the Hawaiian Islands. (Photo by Richard A. Criley.)

time, the dendrobium accounted for $3 \%$ of the lei trade, while iby 1990 it had moved to $17 \%$ and was passing the vanda in popularity as growers of cut sprays found an additional outlet for their flowers.

The cut-flower dendrobiums derive from several species and their hybrids. They are available year-round in a wide assortment of colors from white through pinks and purples to yellows and yellow-brown and yellow-greens and other bicolor combinations. Nearly as many delidrobium flowers for lei-making are imported from Thailand as are marketed by Hawaii growers for this purpose. Some dendrobium orchids have a very light scent, but most have no fragrance. Like the vanda orchid, they can be strung in a variety of ways, and they are long-lasting.

Among the major lei flowers, pikake (Jasminum sambac L.) has the tradition of being special. Introduced by the Chinese, it caught on during the years of the Hawiian court as the lei for courting, for wedding ceremonies, and to honor women in general. These distinctions have blurred as the pikake let-usually several strands wound together-has become popular for graduations and many other occasions. The flowers are picked in bud (tighter for the Oahu market, more open for the Island of Maui) and strung end to end with about 75 buds required per strand. The "double" form is crafted from about 700 buds strung laterally through the corolla tube. With its spiral arrangment of buds, it resembles a huge twisted pearl necklace. While the island of Molokai produces much of the pikake used nowadays in leis, large amounts of pre-strung pikake leis are imported from the Philippines. Plants are stimulated into flowering by defoliation or by pruning about 5 or 6 weeks before the flowers are required.

Nearly any flower can be strung and worn as a lei. Some of the more popular flowers and 
Table 1. Selected lei flowers and foliages used in Hawaiian leis.

\begin{tabular}{|c|c|c|}
\hline$\overline{\text { Common name }}$ & Hawaiian name & Botanical namey \\
\hline$\overline{\text { Lehua }}$ & ohi'a lehua & Metrosideros polymorpha Gaud. \\
\hline Maile & $\begin{array}{l}\text { maile lau nui } \\
\text { maile lau li'i }\end{array}$ & Alyxia oliviformis Gaud. \\
\hline $\operatorname{llima}$ & 'ilima & Sida fallax Walp. \\
\hline Ti leaf & ki, lai'i & Cordyline fruticosa (L.) A. Chevalier \\
\hline Palapalai fern & palapala'i, pala'i & Microlepia setosa $(\mathrm{Sm}$.) Alston \\
\hline Laua'e fern & laua'e & Microsorum scolopendria (N.L. Burman) \\
\hline Maile-scented fern & & Copeland \\
\hline Rose & lokelani & Rosa $\times$ damascena Mill. \\
\hline Green rose & loke-lau & Rosa chinesis Jacq. var. viridiflora Dipp. \\
\hline Gardenia & kiele & Gardenia augusta (L.) Merr. \\
\hline White ginger & 'awapuhi ke'oke'o & Hedychium coronarium Koenig \\
\hline Yellow ginger & 'awapuhi melemele & Hedychium flavescens Roscoe \\
\hline Arabian Jasmine & pikake & Jasminum sambac (L.) Ait. \\
\hline Stephanotis & pua male & Stephanotis floribunda (R. Br.) Brongn. \\
\hline Carnation & poni-moi & Dianthus caryophyllus L. \\
\hline Chinese violet & pakalana & Telosma cordata (Burman f.) Merr. \\
\hline Globe amaranth, bozu & lei-hua, lehua-pepa & Gomphrena globosa $\mathrm{L}$. \\
\hline $\begin{array}{l}\text { Torenia } \\
\text { Olaa Beauty }\end{array}$ & nani-o-ola'a & $\begin{array}{l}\text { Torenia fournieri Lind., } \\
\text { Torenia asiatica } \mathrm{L} .\end{array}$ \\
\hline $\begin{array}{l}\text { Dwarf poinciana } \\
\text { Pride of Barbados }\end{array}$ & 'ohai-ali'i & Caesalpinia pulcherrima (L.) Sw. \\
\hline Tuberose & kupaloke & Polianthes tuberosa L. \\
\hline Cigar flower & pua kika & Cuphea ignea A. DC. \\
\hline Puakenikeni & pua kenikeni & Fagraea berteroana Bentham \\
\hline $\begin{array}{l}\text { Plumeria, Frangipani } \\
\text { Singaporc plumeria }\end{array}$ & melia & $\begin{array}{l}\text { Plumeria rubra L. } \\
\text { Plumeria obtusa } \mathrm{L} .\end{array}$ \\
\hline Crownflower & pua-kalaunu & $\begin{array}{l}\text { Calotropis gigantea (L.) Aiton fil. } \\
\text { Calotropis procera (Aiton) Aiton fil. }\end{array}$ \\
\hline Baugainvillea & pukanawila, pua kepalo & $\begin{array}{l}\text { Bougainvillea } \times \text { buttiana Hltt. Standl. } \\
\text { Bougainvillea glabra Choisy, } \\
\text { Bougainvillea spectabilis Willd. }\end{array}$ \\
\hline Strawflower & pua-pepa & Helichrysum bracteatum (Vent.) Andr. \\
\hline $\begin{array}{l}\text { Vanda 'Miss Joaquim' } \\
\text { ('Agnes Joaquim', 'Miss } \\
\text { Agnes Joaquim') }\end{array}$ & & $\begin{array}{l}\text { Vanda hookeriana Reichenbach fil. } \times \text { Vanda } \\
\text { teres (Roxb.) Lindl. }\end{array}$ \\
\hline Dendrobium orchid & & Dendrobium gouldii $\times D$. phalaenopsis \\
\hline Royal or Triple Ilima & ma'o & Abutilon grandifolium (Willd.) Sweet \\
\hline Abutilon & & $\begin{array}{l}\text { Abutilon pictum (Hook. \& Arn.) Walt cv. } \\
\text { Pleniflorum }\end{array}$ \\
\hline Pin cushion protea & & $\begin{array}{l}\text { Leucospermum cordifolium (Salisb. ex Knight } \\
\text { Fourcade, Leucospermum tottum (Berg.) R. } \\
\text { Br., Leucospermum oleifolium (L.) R. Br. }\end{array}$ \\
\hline Silver tree & & Leucadendron argenteum $\mathrm{R}, \mathrm{Br}$. \\
\hline
\end{tabular}

${ }^{\mathrm{z}}$ After McDonald (1989) and Porter (1972).

${ }^{\mathrm{y}}$ verification of botanic names and authorities by George Staples, Botanist, Bishop Museum, Honolulu. (continued from p. 490 )

foliages used in Hawaiian leis are listed in Table 1 . Small papery flowers of the globe amaranth and strawflower (Helichrysum bracteaturn) may be strung for neckwear or sewn to backings for use as a headband. Roses may be woven with ferns, baby's breath (Gypsophila), statice (Limonium spp.), zinnias, and cockscomb (Celosia) to create glorious crowns. Among the "new" floral materials can be found various leucospermum, Grevillea, Protea, and Serruria species; foliage of Leucudendron argenteum; an Abutilon relative of the ilima, and other species of Cuphea. Stephanotis, puakenikeni (Fagraea berteriana A. Gray), white and yellow gingers (Hedychium spp.), Freesia, and pakalana (Telosma cordata Merr.) are also valued for their fragrances.

Leis are carefully constructed with complementary colors in mind, and may follow themes when they are entered in lei competitions. The early contests in honor of Lei Day (established 1 May 1928) were highly competitive, with
Both leis and headbands can be made by winding a fine string around bits of materials added around a center cord. Another system also used for headbands employs floral and foliar materials sewn to a backing of dried but supple banana stalk skin, pandanus, ti leaf, or similar material.

During the late 1800 s, vendors met arriving steamboats with armloads of leis. Today, at every airport in the state, lei sellers maintain the tradition for arriving airline passengers. Despite the sentiment of "giving," such leis are sold to accomodate those who haven't the time to pick flowers from the backyard to make their own, or who may not even have a backyard in which to pick. Inflation, too, has caught up with the trade. The $\$ 1$ plumeria le is more likely to cost $\$ 3$ or $\$ 4$, while the "double" carnation leis run about $\$ 10$; some of the more exotic leis cost upwards of $\$ 20$ to $\$ 25$ !

Lei stringing is a pleasant if laborious task, and those who do it tend to be women who use any free time they may have to supplement the family income. Patience is most certainly a virtue, especially when threading hundreds of flowers-ilima (Sida spp.) or Cuphea or oha'i ali'i (Casaelpinia pulcherrima)- used in special leis, or when sewing the "double" forms of pikake, stephanotis, or tuberose.

Flower leis are no less beautiful for being often fragile and always impermanent. Not meant to last, they can be put aside and the memory treasured of the occasion or of the giver. Lei specialist Marie McDonald, one of Hawaii's living treasures, reflects on the significance of the lei: "I discovered.. . that the lei was the best way to express beauty and honor. It has universal appeal. It will survive any and all cultural change, for there will always be people who will enjoy and need its beauty to express regard for others and self."

\section{Literature Cited}

Beaumont, J.H. 1951. Development of floriculture in Hawaii. First Floral Clinic Proc., Agr. Econ. Rpt. 8:5-11.

many innovations in design and use of plant material. The designs of some of those early winners have become classics widely reproduced by today's leimakers.

There are six principal construction methods and many variations in lei making. Best known to the visitor is probably the method whereby single flowers are threaded lengthwise or through the side on a single string. One of the simplest requires only the knotting together of leafy stems or vines. The maile lei (Alyxia olivaeformis Gaud.) is prepared this in way, with several strands then twisted together.

Another form uses a single material to braid or plait three or more strands together. Still another version of this method adds other flowers, fruits, or leaves with short stems as part of the braid, which is usually a threestrand backing of a tough, supple cord. This style is called haku and tends to be highly regarded as an art form.

Chinn, J.T. and R.A. Criley. 1982. Plumeria cultivars in Hawaii. Univ. of Hawaii, HITAHR Res. Bul. 158.

Department of Agriculture. 1991. Statistics of Hawaiian agriculture 1990. Hawaii Agr. Stat. Serv., Dept. of Agr., Honolulu.

McDonald, M. 1989. Ka Lei, the leis of Hawaii. (Fourth printing.) Press Pacifica, Kailua, Hawaii.

Porter, JR. 1972. Hawaiian names for vascular plants. Univ. of Hawaii, Coll. Trop. Agr., Hawaii Agr. Expt. Sta. Dept. Paper 1.

RICHARD A. CRILEY

Dept. of Horticulture

University of Hawaii at Manoa 